УДК 378.015. 31: $355.317-057.86(477)$

DOI:

Анжеліка Любас, викладач кафедри іноземних мов та військового перекладу Національної академії сухопутних військ імені гетьмана Петра Сагайдачного, м. Львів

\title{
ПРОФЕСІОГРАМА МАЙБУТНЬОГО ФАХІВЦЯ БОЙОВОГО ТА ОПЕРАТИВНОГО ЗАБЕЗПЕЧЕННЯ
}

У статті проведено дослідження професіограми фахівців бойового та оперативного забезпечення на основі аналізу поняття, структури, ключових ознак, вимог до професійної діяльності майбутніх фахівиів бойового та оперативного забезпечення. Визначено основні види військово-професійної діяльності фахівців бойового та оперативного забезпечення. Встановлено, щзо якість виконання майбутніми фахівиями бойового та оперативного забезпечення професійних функиій, ролей та обов'язків безпосередньо залежить від ряду індивідуально-психологічних особливостей иих фахівців, зокрема професійноі мотивації, професійного мислення, емоційно-вольової сфери, комунікативних здібностей. Обтрунтовано поняття, структуру і зміст професійної компетентності майбутніх фахівців бойового та оперативного забезпечення.

Ключові слова: професіограма; фахівиі бойового та оперативного забезпечення; військовопрофесійна діяльність; професійна компетентність.

Jim. 15.

Anzhelika Lyubas, Lecturer of the Foreign Languages and Military Translation Department National Academy of Ground Forces named after hetman Petro Sahaydachniy

\section{PROFESSIOGRAM OF FUTURE SPECIALISTS OF COMBAT AND OPERATIONAL SUPPORT}

The article deals with the study of professiogram of specialists of combat and operational support on the basis of analysis of the concept, structure, key characteristics and requirements for the professional activity of these specialists. Normative model of military specialty has different forms, but necessarily contains legally fixed in laws, orders, instructions, specifications of the characteristics. An expert model represents a cumulative view about military activity of competent experts. During the studies, the basic kinds of military-professional activity of specialists of combat and operational support are determined. This activity takes place in the combat and peaceful conditions. It is associated with extreme conditions, elements of risk to life and health, and it is aimed at protecting the Fatherland. The main features of the military-professional activity of these specialists are: devotion to the people, regulation of normative legal documents, responsibilities and the need for coordinated cooperation. It has been established that the quality of performance by future specialists of the combat and operational support of their professional duties, roles and responsibilities depends directly on a number of individual psychological peculiarities of these specialists, in particular professional motivation, professional thinking, emotional and volitional sphere and communicative abilities. The concept, structure and content of professional competence of future specialists of combat and operational support are substantiated. Based on the analysis of theoretical studies, we can state that the structure of professional competence of future combat and operational specialists is a combination of intellectual, professional and personal data of these professionals. Despite the fact that the training system of the future specialists of combat and operational support is quite effective, there is a system of practical training, which involves organizing the special exercises and trainings with the aim of working out the practical elements for their better mastering and improvement of the corresponding skills in the basic professional disciplines.

Keywords: professiogram; specialists of combat and operational support; military-professional activity; professional competence.

$\Pi$ остановка проблеми. Актуальність даної статті обумовлена вимогами сьогодення, оскільки важливо сформувати у фахівців бойового та оперативного забезпечення комунікативних навичок взаємодії за європейськими та світовими стандартами.

Аналіз останніх досліджень та публікацій. Аспектами професіографічних досліджень фахівців різних спеціальностей займалися у попередні роки. Зокрема, висвітлення даної проблеми знайшло своє відображення у працях К. Платонова, А. Желаго, Н. Кучеренка, Е. Зеєра та ін.

Проблемі професіографічного дослідження військово-професійної діяльності, але без наголосу на європейські стандарти, була приділено велику увагу в працях науковців і фахівців у галузі психології праці, інженерної та 


\section{ПРОФЕСІОГРАМА МАЙБУТНЬОГО ФАХІВЦЯ БОЙОВОГО ТА ОПЕРАТИВНОГО ЗАБЕЗПЕЧЕННЯ}

військової психології, таких як В.О. Бодров, Г.В. Ложкін, М.В. Макаренко, А.Г. Маклаков, В.Д. Шадріков та ін.

Питанням професійної компетентності майбутніх офіцерів присвячені роботи О. Барабанщикова, Д. Іщенка, а складові професійної компетентності військового фахівця розглядалися у дослідженнях А. Аронова, М. Бастрікова, Ю. Варданяна та ін.

Мета статті - проаналізувати професіограми фахівців бойового та оперативного забезпечення підрозділів Збройних Сил України.

Відповідно до поставленої мети сформулюємо основні завдання:

- 3'ясувати сутність і структуру військовопрофесійної діяльності фахівців бойового та оперативного забезпечення, визначити i проаналізувати іiі основні види та ознаки;

- розглянути структуру і зміст військовопрофесійної компетентності майбутніх офіцерів та провести аналіз їх професійних знань, вмінь та навичок.

Виклад основного матеріалу. Професіограма (від лат. Professio - спеціальність і gramma запис) - являє систему: ознак, що описують професію і спеціальність; вимог, які професія пред'являє до працівника; психологічних характеристик, яким повинен відповідати фахівець конкретної професії. По-перше, професіограма визначає особливості і структуру професійної діяльності та основні вимоги до фізіологічних і психологічних характеристик фахівця; по-друге, являє розроблену науково обгрунтовану систему норм і вимог професії до конкретних видів діяльності, а також до індивідуально-особистісних властивостей фахівця, що дозволяє виконувати ефективно вимоги професії, яка в той же час створює умови, необхідні для розвитку особистості самого фахівця $[2,281]$.

А.К. Маркова розглядає професіограму як науково обгрунтовані норми і вимоги професії до видів професійної діяльності та якостей особистості фахівця, які дозволяють йому ефективно виконувати вимоги професії, отримувати необхідний для суспільства продукт і водночас створюють умови для розвитку особистості самого працівника. Також, авторка зазначає, що професіограма - це узагальнена еталонна модель успішного фахівця в даній області [9, 14].

Відомий психолог К.К. Платонов проаналізував професійну діяльність військовослужбовців та розробив їі модель, сформулювавши принципи професіографії. Вона складається 3 трьох описаних моделей: нормативної, експертної та емпіричної.

Нормативна модель військової спеціальності має різні форми, але обов'язково містить юридично закріплені в законах, наказах, інструкціях та настановах характеристики нормативної моделі.

Експертна модель являє собою сукупну думку про військову діяльність компетентних експертів, тобто фахівців. Експертна модель складається шляхом збору думок конкретних фахівців. Можна зробити експертну модель будь-якої спеціальності - моряка, артилериста і т.д. Слабкість цієї моделі полягає в тому, що через специфіку різних видів військової діяльності кожна група експертів може дати їм різне трактування і моделі можуть в принципі різнитися між собою.

Емпірична модель являє собою опис вимог до індивідуальних якостей фахівця, складена на основі діагностичних даних про діяльність найбільш успішних фахівців [11, 34].

Військова служба є видом людської діяльності, яка характеризується не тільки високою соціальною значимістю, але й виходить за межі буденної діяльності та пов'язана 3 особливими умовами. Військовослужбовці завжди розглядались як частка суспільства, у якій знаходили відображення всі соціально-економічні та політичні процеси, що відбуваються в суспільстві, а також всі закономірності змін міжнародної обстановки $[8,56]$.

Військово-професійна діяльність - це діяльність щодо захисту Вітчизни, у якій можна виділити дві складові: діяльність в бойових умовах (бойова діяльність) і повсякденна діяльність (у мирних умовах) $[11,74]$. Бойова діяльність - це активність військовослужбовців щодо досягнення цілей збройної боротьби. Ця діяльність дуже специфічна за своїми цілями і завданнями, умовами, засобами, труднощами, психологічним змістом. Вона має свої психологічні закономірності, певну внутрішню структуру, мотиви, способи, через які на її перебіг впливає низка факторів: військово-професійні, бойова підготовка особового складу, військово-технічні і психологічні, робота з особовим складом [6, 92]. У бою вирішуються складні завдання, пов'язані з небезпекою для життя, знищенням цінностей величезними руйнуваннями, втратами людей та техніки. Ведення бою пов'язане 3 підвищенням моральної та юридичної відповідальності за точне виконання обов'язків, вимагає психічного та фізичного напруження сил військовослужбовців. Головним соціальним мотивом бойової діяльності військовослужбовців $є$ захист своєї Батьківщини. 


\section{ПРОФЕСІОГРАМА МАЙБУТНЬОГО ФАХІВЦЯ БОЙОВОГО}

\section{ТА ОПЕРАТИВНОГО ЗАБЕЗПЕЧЕННЯ}

Інший вид військово-професійної діяльностідіяльність у звичайних, мирних умовах. На перший погляд вона навряд чи відрізняється від тієї діяльності, якою людина займалась до початку військової служби. Людина, яка виявила бажання проходити військову службу, змушена відмовитись від звичних стереотипів поведінки. Це пов'язано з особливостями проходження військової служби: здійснення принципу єдиноначальності передбачає усвідомлене підпорядкування своєї волі та бажань, волі іншої людини - командира, що в соціальнопсихологічному плані супроводжується обмеженням ступеня особистої свободи і обумовлена суворою регламентацією військової служби [8, 46].

Основним підвидом професійної діяльності військовослужбовців є службова діяльність. Вона характеризується сукупністю режимних, охоронних, захисних заходів, які проводяться в мирний час за надзвичайних обставин та у воєнний час з метою забезпечення безпеки держави $[12,11]$.

До загальних ознак професійної діяльності військовослужбовців можна віднести: соціальну обумовленість і регламентованість військової праці законодавством, статутами, наказами; комплексність, що зумовлена одночасною інтенсивною підготовкою військовослужбовця в процес професійної діяльності практично в усі системи праці: “людина - людина", “людина техніка", “людина - знакова система”; екстремальність умов виконання функціональних обов'язків; колективний характер праці $[13,14]$. Особливостями професійної діяльності військовослужбовця $\epsilon$ віддане служіння Українському народові, сумлінне і чесне виконання військових обов'язків, хоробрість, ініціативність і дисциплінованість, виконання наказів командирів, підвищення рівня військових професійних знань, поважання бойових та військових традицій, пильність, ведення бойових дій до повного виконання поставленого завдання, дотримання правил військових Статутів, ввічливої поведінки та ін.

Отже, військова діяльність розглядається як процес виконання військовослужбовцями завдань військової служби, вивчення бойової техніки, несення бойового чергування, ведення бойових дій проти ворога та ін. У ній виділяються наступні компоненти: усвідомлення військовослужбовцем поставленого перед ним завдання; оформлення мотивів і вироблення планів майбутніх дій; застосування засобів і прийомів діяльності; регулювання дій у відповідності до завдання; оцінка та звірення отриманих результатів 3 тим, що було потрібно або пропонувалося зробити.

3 метою складання професіограми майбутнього фахівця бойового та оперативного забезпечення, як суб'єкта навчальної діяльності, потрібен аналіз його спрямованості, самовизначення психологічного типу особистості, мотиваційної та когнітивної сфер, соціального досвіду.

У результаті вивчення професійної діяльності військових фахівців А.М. Желаго визначив зміст професійно важливих якостей військовослужбовців до яких він відніс: уміння швидко, вірно вибрати форму відносин у залежності від психологічного стану й індивідуальних якостей особи, яка підлягає конвоюванню, здатність визначити можливі альтернативні шляхи вирішення однієї і тієї ж ситуації, вірно визначити напрямок діяльності, відчуття наявності проблеми там, де здавалось, що вже все вирішено та ін. $[4,5]$.

Досліджуючи професійнудіяльність військових фахівців Н.С. Кучеренко визначила ряд індивідуально-психологічних особливостей, які впливають на виконання ними службово-бойових завдань: професійна мотивація, професійне мислення, емоційно-вольова сфера, комунікативні здібності [7, 23].

До структури суб'єкту діяльності (поряд із спрямованістю, професійно-важливими якостями та професійно-значущими психофізіологічними властивостями) Е.Ф. Зеєр включає професійну компетентність. Він визначає їі як сукупність професійних знань, вмінь, а також способів виконання професійної діяльності. Її основними компонентами, на думку дослідника, є соціальноправова, спеціальна, персональна та ауто компетентності $[5,35]$.

На сьогодні, існує багато визначень професійної компетентності. Вітчизняні вчені вважають, що "професійна компетентність" визначається як знання, вміння, навички, способи та прийоми їх реалізації в діяльності, спілкуванні, розвитку особистості. До елементів даної компетентності вони відносять здатність ефективно розв' язувати практичні завдання щодо соціалізації особистості, яка розвивається, сприяє забезпеченню внутрішніх умов, діяльнісної інтеграції особистості у суспільстві за рахунок розвитку ціннісних орієнтацій щодо природи, суспільства; формування практичних умінь діяльнісної, суспільно-бажаної або прийнятої самореалізації.

На думку А.О. Деркача, професійна компетентність - головний когнітивний компонент підсистеми професіоналізму 


\section{ПРОФЕСІОГРАМА МАЙБУТНЬОГО ФАХІВЦЯ БОЙОВОГО ТА ОПЕРАТИВНОГО ЗАБЕЗПЕЧЕННЯ}

діяльності, сфера професійного розвитку, система знань, яка постійно розширюється, що дозволяє здійснювати професійну діяльність із високою продуктивністю. Структура й зміст професійної компетентності визначаються специфікою професійної діяльності та приналежністю професії до певного класу.

Зарубіжні науковці М. Вудкок, Д. Френсіс вважають, що професійна компетентність формується лише у взаємозв' язку із соціальними установками фахівця, зокрема через: 1) професійну ідентичність - прийняття професійних норм і відповідальностей через процес професійної соціалізації; 2) професійну етику - опанування етичниминормамипрофесіі; 3) конкурентоспроможність - здатність до ефективної професійної діяльності в структурі ринкових відносин; 4) прагнення до наукового удосконалення - необхідність отримати нові знання у процесі дослідницької діяльності; 5) мотивацію до продовження освіти - потребу в постійному професійному самовдосконалення і відповідно до вимог сучасності [10, 47].

Більшість науковців, розглядаючи проблему компетентності, стверджують, щоб бути компетентним фахівцем, недостатньо мати фундаментальну, теоретичну i практичну підготовку. Компетентний фахівець має бути творчою особистістю, професійно та психологічно готовим і здатним до ефективного застосовування набутих знань у професійній діяльності. Більше того, В.В. Ягупов та В.I. Свистун, спираючись на таке розуміння поняття “професійна компетентність”, обгрунтували провідний методологічний підхід (суб' єктивно-діяльнісний) до визначення компетентності будь-якого фахівця. Суб' єктивно-діяльнісний підхід визначення компетентності фахівця враховує різні аспекти його діяльності: інтелектуальний (когнітивний), професійний (фаховий) і особистісний (суб'єктивний), які взаємодоповнюють один одного, сприяють їх комплексному і системному прояву, при необхідності можуть компенсувати недостатній розвиток певних показників його компетентності $[14,25]$.

Військово-професійна компетентність це інтегративна якість військовослужбовців, що представляє сукупність професійно значущих якостей, здатність і готовність розв'язувати професійні проблеми і завдання, що постають у реальних ситуаціях військової діяльності, 3 використанням знань, навичок, умінь, професійного й життєвого досвіду, цінностей і культури. У загальному розумінні військовопрофесійна компетентність - це військовопрофесійна підготовленість і здатність окремого військовослужбовця або військового підрозділу до виконання бойових завдань і обов'язків із несення військової служби [3, 434]. У структурі військовопрофесійної компетентності майбутнього офіцера - захисника Батьківщини й миротворця обов'язковими $є$ компетенції у галузі військового права, стройової, фізичної і вогневої підготовки. Компетентність військовослужбовців як військових професіоналів утворюється системою ключових, базових (загальних) і спеціальних компетентностей, що формуються у процесі навчання, розглядаються як результат освіти $і$ розвиваються у ході військово-професійної діяльності. Професійна компетентність майбутнього військового фахівця визначається його індивідуальними здібностями, мотивованим прагненням до безперервної самоосвіти і самовдосконалення, творчим і відповідальним ставленням до справи. Рівень сформованості професійної компетентності визначається також якістю набутої професійної освіти, суб'єктним досвідом навчальної і професійної діяльності.

Міжкультурна компетентність належить до ключових компетентностей у структурі професійної компетентності майбутнього фахівця бойового та оперативного забезпечення.

У науковій праці “Компетентнісний підхід до підготовки фахівців у системі вищої освіти” B.В. Ягупов та В.І. Свистун запропонували структуру професійної компетентності фахівців, яка заслуговує на те, щоб бути використаною при моделюванні підготовки військових фахівців. Така структура включає:

1) ключова компетентність (загальнокультурна, комунікативна, міжкультурна, моральна, політична, соціальна, інформаційна, етична, екологічна, валеологічна);

2) загальнонаукова компетентність (методологічна, теоретична, методична, дослідницька);

3) загальнопрофесійна компетентність (загальнофахова, економічна, технічна, правова, психологічна, педагогічна);

4) фахова компетентність (технологічна);

5) функціональна компетентність (стратегічна, менеджерська, управління суб’єктами та об'єктами діяльності, виконавча);

6) особистісна компетентність (мотиваційна, аутопсихологічна, регулятивна, адаптивна, навчальна) $[15,6]$.

Аналізуючи структуру професійної компетентності фахівців військового спрямування можна зробити висновок, що компетентність це вузлове поняття, що поєднує в собі: інтелектуальну й навичкову складову освіти; ідеологію інтерпретації змісту освіти, що 


\section{ПРОФЕСІОГРАМА МАЙБУТНЬОГО ФАХІВЦЯ БОЙОВОГО}

\section{ТА ОПЕРАТИВНОГО ЗАБЕЗПЕЧЕННЯ}

формується “від результату”; інтегративну особливість, тому що вона вбирає в себе знання, уміння, навички та якісні характеристики особистості [14, 43].

Існуюча система підготовки військовослужбовців Збройних Сил України спрямована на формування в них відповідних компонентів професійної компетентності, а саме професійних знань, вмінь та навичок, якими повинен володіти кожен фахівець бойового та оперативного забезпечення. Вони повинні володіти конкретними знаннями про форми й способи ведення сучасної збройної боротьби; розуміти на системній основі відмінності між війнами різних поколінь та можливостями протиборчих сторін, що брали в них участь; володіти питаннями підготовки та ведення війн майбутнього; вміти прийняти нешаблонні рішення (здійснити маневр у фланг та в тил противника, приховано розташовувати вогневі засоби у опорних пунктах та виводити їх на вогневі позиції безпосередньо з початком атаки противника); вміти швидко змінювати побудову бойового порядку та способів ведення бойових дій залежно від тактичної ситуації, що складається; вивчати основи ведення військової розвідки; застосовувати свої знання під час виконання завдань; проводити тренування для вироблення навичок, які можна застосувати під час ведення бойових дій.

Виходячи 3 вивчення та дослідження досвіду локальних війн і збройних конфліктів останніх десятиліть, проведеним аналізом встановлено необхідність спрямовувати зусилля на прогнозуванні можливого розвитку форм i способів збройної боротьби, завдяки результатам наукових досліджень вносити зміни у навчальний процес підготовки фахівців бойового та оперативного забезпечення, який базувався на вимогах та положеннях освітньо-кваліфікаційних характеристик, освітньо-професійних програм підготовки військових фахівців [1, 12].

Існує система практичного вишколу майбутніх фахівців бойового та оперативного забезпечення, яка передбачає організацію спеціальних навчань 3 метою відпрацювання практичних елементів й удосконалення відповідних вмінь 3 основних фахових дисциплін.

Незважаючи те, що система підготовки майбутніх фахівців бойового та оперативного забезпечення є досить ефективною, до шляхів підвищення якості навчального процесу можемо віднести $[1,15]$ :

- забезпечення постійного корегування навчальних програм та робочих програм навчальних дисциплін, при узагальнені досвіду застосування військ у сучасних збройних конфліктах;

- методику проведення занять;

- прагнення до самовдосконалення;

- поглиблене вивчення питань ведення бойових дій.

Висновки. Отже, військово-професійна діяльність $є$ діяльністю, яка пов'язана 3 екстремальними умовами й елементами ризику для життя і здоров'я та спрямована на захист Вітчизни.

Основними ознаками військово-професійної діяльності майбутніх фахівців бойового та оперативного забезпечення є: самовіддане служіння народу, соціальна зумовленість та регламентованість нормативно-правовими документами, екстремальність умов виконання професійних функцій, ролей та обов'язків, необхідність скоординованої співпраці.

На основі аналізу теоретичних досліджень можемо стверджувати, що структура професійної компетентності майбутніх фахівців бойового та оперативного забезпечення окреслена у наукових розвідках як складне поєднання між інтелектуальними, професійними та особистісними даними згаданих професіоналів, які безпосередньо впливають на професійну діяльність і потребують постійного педагогічного корегування, з урахуванням вимог до необхідного рівня сформованості, відповідних компонентів цієї компетентності.

Інваріантними компонентами професійної компетентності майбутніх фахівців бойового та оперативного забезпечення визначено:

- ключову компетентність, що включає загальнокультурну, комунікативну, міжкультурну, навчальну, мотиваційну, політичну, соціальну, інформаційну, етичну, екологічну, валеологічну компетентності, а також відповідні знання, вміння та навички;

- загальнонаукову компетентність, яка охоплює методологічну, теоретичну, методичну, дослідницьку компетентності, а також відповідні знання, вміння та навички;

- загальнопрофесійну компетентність, що окреслює загальнофахову, економічну, технічну, правову, психологічну, педагогічну компетентності, а також відповідні знання, вміння та навички;

- вузькопрофесійну компетентність, яка включає технологічну компетентність, а також відповідні знання, вміння та навички;

- функціональну компетентність, яка містить стратегічну, менеджерську компетентності, компетентність в управлінні суб'єктами та об’єктами діяльності, виконавчу компетентність, 


\section{ПРОФЕСІОГРАМА МАЙБУТНЬОГО ФАХІВЦЯ БОЙОВОГО ТА ОПЕРАТИВНОГО ЗАБЕЗПЕЧЕННЯ}

компетентність скоординованої співпраці, а також відповідні знання, вміння та навички;

- особистісну компетентність, яка охоплює аутопсихологічну, регулятивну, адаптивну, компетентності, а також відповідні знання, вміння та навички.

Відсутність або недостатня сформованість хоча б одного $з$ цих компонентів здійснює суттєвий вплив на рівень виконання військовими фахівцями професійних функцій, ролей та обов'язків.

Перспективи подальших досліджень полягають у аналізі методологічних основ формування міжкультурної компетентності майбутніх фахівців бойового та оперативного забезпечення.

\section{ЛІТЕРАТУРА}

1. Аналіз і пошук перспективних шляхів вдосконалення психолого-педагогічного забезпечення підготовки офіцерських кадрів сухопутних військ: заключний звіт про науково-дослідну роботу / [Мацевко Т.М., Федак С.С., Романишин А.М. та ін.], Л.: Науковий центр Сухопутних військ Національної академії сухопутних військ, 2014. 174 с. ( інв. № 1112 від 12.12 .14 р.)

2. Березкина, Т. Е. Организационноуправленческая деятельность юриста: учебник и практикум для бакалавриата и магистратуры) [Електронний ресурс]. / Т. Е. Березкина, А.А. Петров. - 2-е изд., перераб. и доп. - М.: Издательство Юрайт, 2017. - 410 с. (Серия: Бакалавр и магистр. Академический курс. - Режим доступу: ISBN 978 5-534-03321-2.

3. Ефремов О.Ю. Военная педагогика: учебник для вузов / О.Ю. Ефремов. - С Пб.: Питер, 2008. $-640 \mathrm{c}$.

4. Желаго А.М. Соціально-психологічні детермінанти професійного становлення командира підрозділу внутрішніх військ МВС України: автореф. дис. на здобуття наук. ступеня канд. психол. наук: спец. 19.00.09 "Психологія діяльності в особливих умовах” / А.М. Желаго. X., 2014. - 24 c.

5. Зеер Э.Ф. Психология профессии: учеб. пособие для студ. вузов / Зеер Э. Ф. - 4-е изд., перераб., доп - М.: Акад. проект, Фонд “Мир”, 2006. - 336 c.

6. Караяни А. Г. Психологическое обеспечение боевых действий личного состава Сухопутных войск в локальных военных конфликтах: дис. на соискание науч. степеня доктора психол. наук: 19.00.14 / А. Г. Караяни. - М., 1998. - 355 с.

7. Кучеренко Н. С. Психологічне забезпечення службово-бойової підготовки майбутніх офіцерів технічного профілю Національної гвардії України: автореф. дис. на здобуття наук. ступеня канд. психол. наук.: спец. 19.00.09 “Психологія діяльності в особливих умовах" / Н. С. Кучеренко - X., 2016. -28 c.

8. Маклаков А.Г. Психология и педагогика. Военная психология / А. Г. Маклаков. - С. Пб.: Питер, 2005. - 464 с.

9. Маркова А. К. Психология профессионализма [Електронний ресурс] / А. К. Маркова.-М.: Знание, 1996. - 308 c. - Режим доступу: www.p-lib.ru

10. Маслак Л.П. Формування професійної іншомовної компетентності радіоінженерних спеціальностей: автореф. дис. на здобуття наук. ступеня канд. пед. наук: спец. 13.00.04 “Теорія і методика професійної освіти” / Л. П. Маслак Ж., 2010. - 18 с.

11. Платонов К.К. Структура и развитие личности / К.К. Платонов. - М.: Наука, 1986. $255 \mathrm{c}$.

12. Полторак С.Т. [та інші]. Основи підготовки підрозділів спеціального призначення внутрішніх військ: Навчальний посібник / заг. ред. С.Т. Полторака. - Х.: Акад. ВВ МВС України, 2012. - 448 с.

13. Приходько I. I. Професійний психологічний відбір майбутніх офіцерів внутрішніх військ МВС України: монографія / I. I. Приходько - Х.: Акад. ВВ МВС України, 2008. - 190 с.

14. Удосконалення програм підготовки та навчальних дисциплін професійного спрямування для курсантів випускних курсів Національної академії сухопутних військ імені гетьмана Петра Сагайдачного: заключний звіт про науководослідну роботу / [Слюсаренко А.В., Черненко А.Д., Шевченко О.М. та ін..], Л.: Науковий центр Сухопутних військ Національної академії сухопутних військ, 2016. - 174 с. (інв. № 1623 від 16.07.16 р.)

15. Ягупов В. В. Компетентнісний підхід до підпотовки фахівцівусистемівищоїосвіти/В.В. Ягупов, В. I. Свистун // Наукові записки. Педагогічні, психологічні науки та соціальна робота. - 2007. Том 71. - C. 3-8.

\section{REFERENCES}

1. Matsevko, T.M., Fedak, S.S. \& Romanyshyn, A.M. et al (2014). Analiz i poshuk perspektyvnykh shliakhiv vdoskonalennia psykholoho-pedahohichnoho zabezpechennia pidhotovky ofitserskykh kadriv sukhoputnykh viisk [Analysis and search for promising ways to improve the psychological and pedagogical provision of training of officer personnel of the ground forces]. Report on research work. Competency Officers, inv. Number 1112 from 12.12.14. [in Ukrainian]. 
2. Berezkina, T. Ye. (2017). Organizatsionnoupravlencheskaya deyatelnost yurista: uchebnik $i$ praktikum dlya bakalavriata $i$ magistratury [Organizational and administrative activity of a lawyer]. Moscov: Yurayt Publ., 410 p. [in Russian].

3. Yefremova, O.Yu. (2008). Voennaya pedagogika [Military Pedagogy]. Saint Petersburg: Piter, 640 p. [in Russian].

4. Zhelaho, A. M. (2014). Sotsialno-psykholohichni determinanty profesiinoho stanovlennia komandyra pidrozdilu vnutrishnikh viisk MVS Ukrainy [Sociopsychological determinants of the professional formation of the commander of the unit of internal troops of the Ministry of Internal Affairs of Ukraine]. Kharkiv, 24 p. [in Ukrainian].

5. Zeer, E. F. (2006). Psikhologiya profesii [Psychology of the profession]. Moscow: Akad. Proekt Publ; Fund Peace,336p. [in Russian].

6. Karayani, A.G. (1998). Psikhologicheskoe obespechenie boevykh deystviy lichnogo sostava Sukhoputnykh voysk v lokalnykh voennykh konfliktakh [Psychological support of combat operations of the personnel of the Ground Forces in local military conflicts]. Moscow, 355 p. [in Russian].

7. Kucherenko, N. S. (2016) Psykholohichne zabezpechennia sluzhbovo-boiovoi pidhotovky maibutnikh ofitseriv tekhnichnoho profiliu Natsionalnoi hvardii Ukrainy.[The psychological support of military and combat training of future officers of the technical profile of the National Guard of Ukraine]. Extended abstract of candidate's thesis. Kharkiv,28 p. [in Ukrainian].

8. Maklakov, A. G. (2005). Psikhologiya i pedagogika. Voennaya psikhologiya [Psychology and pedagogy. Military psychology]. Saint Petersburg: Piter, 464 p. [in Russian].

9. Markova, A. K. (1996). Psikhologiya professionalizma [Psychology of professionalism]. Moskov: Knowledge, 308 p. [in Russian].
10. Maslak, L. P. (2010). Formuvannia profesiinoi inshomovnoi kompetentnosti radioinzhenernykh spetsialnostei [Formation of professional foreign language competence in radio engineering specialties]. Extended abstract of candidate's thesis. Zhytomyr, 18 p. [in Ukrainian].

11. Platonov, K. K. (1986). Struktura i razvitie lichnosti [Structure and development of the person]. Moscow: Science, 255 p. [in Russian].

12. Poltorak, S. T. (Ed.). (2012). Osnovy pidhotovky pidrozdiliv spetsialnoho pryznachennia vnutrishnikh viisk: navch. posib. [Fundamentals of training special units of internal troops]. Kharkiv: Akad. VV MVS Ukrainy Publ., 448 p. [in Ukrainian].

13. Prykhodko, I. I. (2008). Profesiinyi psykholohichnyi vidbir maibutnikh ofitseriv vnutrishnikh viisk MVS Ukrainy [Professional psychological selection of future officers of internal troops of the Ministry of Internal Affairs of Ukraine]. Kharkiv: Akad. VV MVS Ukrainy Publ., 190 p. [in Ukrainian].

14. Sliusarenko, A.V., Chernenko, A.D. \& Shevchenko, O.M. et al. Udoskonalennia prohramm pidhotovky ta navchalnykh dystsyplin profesiinoho spriamuvannia dlia kursantiv vypusknykh kursiv Natsionalnoi akademii sukhoputnykh viisk imeni hetmana Petra Sahaidachnoho [Improvement of training programs and professional subjects for graduates of the National Academy of Ground Forms named after Hetman Petra Sagaidachnogo]. Report on research work Program-A, inv. Number 1623 from 16.07.16 in National Academy of Ground Forces named after Petro Sahaidachnyi. [in Ukrainian].

15. Yahupov, V.V. \& Svystun, V.I. (2007). Kompetentnisnyi pidkhid do pidhotovky fakhivtsiv u systemi vyshchoi osvity [Competent approach to the training of specialists in the system of higher education]. Proceedings. Pedagogical, psychological sciences and social work, vol. 71, pp. 3-8. [in Ukrainian].

Стаття надійшла до редакції 15.03.2018

\section{G5808NC2G58)}

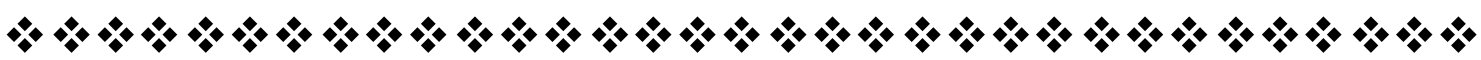

“....Tоодиноқа, недовголітня досвідченість, хоч би їй було сорок чи п'ятдесят роқів, нішо перед досвідом кількох століть, в якому зосередилися результати педагогічної діяльності незчисленної кількості, принаймні таких самих як $i$ він, педагогів, між яқими було багато видатних талантів та незвичайних осіб, які віддали всі свої сили справі виховання".

Констянетин Учинський украӥнський педагог

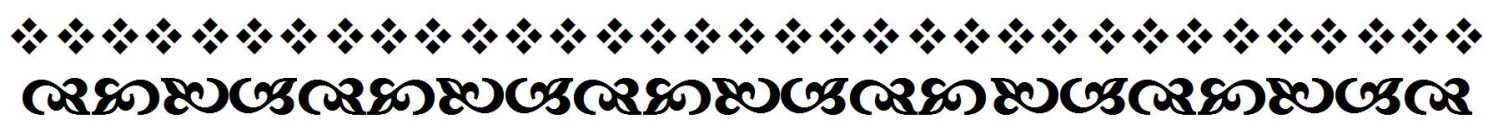

Молодь і ринок №5 (160), 2018 